\title{
The Overall Design of the Project Teaching of Economic Law Courses
}

\author{
Guanghua Xiang \\ College of Economics and Management, HuBei Three Gorges Polytechnic, Yichang Hubei, 443000, China
}

Keywords: Economic law, Project teaching, Overall design.

\begin{abstract}
Higher vocational education is actually pre-job education, but there often exists the problem that school education divorced from profession. As for how to solve this problem, the direction of reform should first determine the goal of teaching is to foster and improve the students' quality and ability, while project teaching is a good form of teaching to achieve this goal.
\end{abstract}

\section{Overview of project teaching}

The project teaching method is a teaching activity by teachers and students through the joint implementation of a complete project work. It is a task - driven teaching focusing on specific projects to enable students to gain knowledge and skills in the process of completing tasks, a teaching form integrating theoretical knowledge, practical operation and quality training.

\section{Overall design of the project teaching of economic law courses in higher vocational colleges}

\section{First, Course construction}

The nature and function of the course

Economic law is the basic course of economic management. It's a very hands-on course which can play a supporting role on the cultivation of students' comprehensive vocational accomplishment and vocational ability for getting a job in the future.

Design philosophy and ideas

The design philosophy of the economic law course is: The design of the course in general reflects the higher vocational teaching requirements such as"Taking the project as the carrier, driven by tasks, the ability training as the standard"; "Taking employment as the orientation, based on current, learning to use, the future taken into account; With the students as the core, teaching interaction, cultivating students' fond of teaching and learning well", realizing integration of teaching, learning and practice as well as the goal on cultivation of knowledge ability and quality.

The design idea of the course of economic law is that the legal knowledge should be properly decomposed for solving the students' future required ability on employment, work and life, forming a curriculum content system oriented by capacity-building, realizing two supports: (1) Support for practical application. The legal knowledge and corresponding abilities involved in teaching content can help students solve the general legal problems encountered in real life; (2)Support for entrepreneurial services. The nine scenarios involved in the project basically include the most basic legal issues involved in the start-up process.

\section{Second, the contents of course}

\section{Organization and arrangement of teaching contents}

The economic law system generally includes: the basic theory of economic law; Market principal method; Market regulation; Macroeconomic regulation; Social security law; Legal settlement of economic disputes.Depending on the object and work requirements of the future career and the differences between the economic management and the economic law content requirements, it integrates the economic law course content, adopting the ways of creating a real situation and 
highlighting the professional atmosphere according to the teaching objectives and employment prospects of the higher vocational colleges, the contents of economic law courses are divided into two modules: basic quality and ability project. In specific teaching, a number of subprojects are further designed in each large project.

The course projects and task design of The Economic Law

(1) Basic quality module

\begin{tabular}{|c|c|c|c|c|}
\hline \multirow{2}{*}{$\begin{array}{l}\text { vocational } \\
\text { ability }\end{array}$} & \multicolumn{2}{|c|}{$\begin{array}{l}\text { The corresponding } \\
\text { module }\end{array}$} & \multirow[b]{2}{*}{ Teaching content } & \multirow[b]{2}{*}{ Related supporting theory } \\
\hline & $\begin{array}{l}\text { The } \\
\text { first } \\
\text { level }\end{array}$ & The second level & & \\
\hline $\begin{array}{l}\text { Basic } \\
\text { Quality }\end{array}$ & $\begin{array}{l}\text { Theory } \\
\text { module }\end{array}$ & $\begin{array}{c}\text { Cognitive law and } \\
\text { economic law, } \\
\text { setting up the rule } \\
\text { consciousness }\end{array}$ & Overview of law & $\begin{array}{l}\text { The basic theory of Law } \\
\text { The basic theory of Economic Law }\end{array}$ \\
\hline
\end{tabular}

(2) Ability project module

This module is mainly on the basis of the content involved in economic law curriculum, set up into nine big projects on landscape orientation.

\begin{tabular}{|c|c|c|c|c|c|}
\hline $\begin{array}{c}\text { Serial } \\
\text { numb } \\
\text { er }\end{array}$ & \multicolumn{2}{|c|}{ Projects } & $\begin{array}{l}\text { Knowledge } \\
\text { requirements }\end{array}$ & $\begin{array}{l}\text { Professional } \\
\text { ability }\end{array}$ & Teaching advice and instruction \\
\hline \multirow[b]{2}{*}{1} & \multirow[b]{2}{*}{$\begin{array}{l}\text { Basic } \\
\text { theory } \\
\text { discus } \\
\text { sion }\end{array}$} & $\begin{array}{l}1.1 \text { Clear } \\
\text { legal } \\
\text { relationshi } \\
\text { p }\end{array}$ & $\begin{array}{l}\text { 1.To grasp the } \\
\text { concept of legal } \\
\text { relationship; } 2 \text {. The } \\
\text { components of } \\
\text { legal relations; } 3 \text {. } \\
\text { Legal relationship } \\
\text { main body's legal } \\
\text { responsibility }\end{array}$ & $\begin{array}{l}\text { Straighten out the } \\
\text { legal relationship } \\
\text { of the parties }\end{array}$ & $\begin{array}{l}\text { Task 1-1: setting situation, dividing the } \\
\text { students into two groups including party } \\
\text { group and lawyer group, carrying on scenario } \\
\text { simulation play, lawyer group receives } \\
\text { consulting case from party group and does } \\
\text { corresponding record and discusses the } \\
\text { controversies of the case mutually. }\end{array}$ \\
\hline & & $\begin{array}{c}1.2 \\
\text { Effective } \\
\text { agent } \\
\text { cognizance }\end{array}$ & $\begin{array}{l}\text { 1. To grasp the } \\
\text { concept of the } \\
\text { agent } \\
\text { 2. Master the rules } \\
\text { of the exercise of } \\
\text { authority } \\
\text { 3.The cognizance } \\
\text { of unauthorized } \\
\text { agency, apparent } \\
\text { agency }\end{array}$ & $\begin{array}{l}\text { 1.Study relevant } \\
\text { laws and } \\
\text { regulations, } \\
\text { improve the } \\
\text { ability of } \\
\text { knowing and } \\
\text { usage of the law } \\
\text { 2. Play team } \\
\text { cooperation } \\
\text { spirit, cooperate } \\
\text { to complete the } \\
\text { task } \\
\text { 3. The cultivation } \\
\text { and improvement } \\
\text { of self-study } \\
\text { skills and } \\
\text { expression } \\
\text { abilities }\end{array}$ & $\begin{array}{l}\text { Task 1-2: 1. Divided into two groups, assign } \\
\text { different tasks, learn relevant legal } \\
\text { knowledge, and collect cases. } 2 \text {. The first } \\
\text { group will discuss and learn relevant legal } \\
\text { knowledge, work together and collect cases. } \\
\text { 3. The second group will supplement, correct } \\
\text { and evaluat the problems existing in the first } \\
\text { group teaching. }\end{array}$ \\
\hline 2 & $\begin{array}{l}\text { Handl } \\
\text { e the } \\
\text { relatio } \\
\text { nship } \\
\text { betwe } \\
\text { en } \\
\text { partne } \\
\text { rs }\end{array}$ & $\begin{array}{l}\text { 2.1 Clear } \\
\text { partners' } \\
\text { methods of } \\
\text { responsibil } \\
\quad \text { ity }\end{array}$ & $\begin{array}{l}\text { 1.Master the } \\
\text { enterprise } \\
\text { investors' methods } \\
\text { of responsibility } \\
\text { 2.Clear partners' } \\
\text { methods of } \\
\text { responsibility }\end{array}$ & $\begin{array}{l}\text { Train the } \\
\text { students' ability } \\
\text { of correctly } \\
\text { dealing with } \\
\text { economic law } \\
\text { problems by } \\
\text { using economic } \\
\text { laws and } \\
\text { regulations, } \\
\text { improve the } \\
\text { students' ability } \\
\text { of practical use of }\end{array}$ & $\begin{array}{l}\text { Task 2-1: } \\
\text { 1. According to the typical cases provided by } \\
\text { teachers, students are divided into groups, } \\
\text { taking group as a unit analyzing and } \\
\text { discussing cases. } \\
\text { 2, The teacher will discuss the problem } \\
\text { presented in the student discussion and give } \\
\text { guidance in time at the scene. } \\
\text { 3, The teacher will review and summarize } \\
\text { according to the discussions of each group. }\end{array}$ \\
\hline
\end{tabular}




\begin{tabular}{|c|c|c|c|c|c|}
\hline & & & & $\begin{array}{l}\text { the laws and } \\
\text { regulations }\end{array}$ & \\
\hline & & $\begin{array}{l}2.2 \text { Draw } \\
\text { up } \\
\text { partnership } \\
\text { agreement }\end{array}$ & $\begin{array}{l}\text { 1. Master the } \\
\text { establishment of } \\
\text { the partnership } \\
\text { 2. Learn to draw } \\
\text { up a partnership } \\
\text { agreement and } \\
\text { define the } \\
\text { relationship } \\
\text { between partners. } \\
\text { 3. Apply the } \\
\text { knowledge to } \\
\text { handle legal } \\
\text { affairs in the } \\
\text { partnership } \\
\text { process }\end{array}$ & $\begin{array}{l}\text { 1. Learn to draw } \\
\text { up a partnership } \\
\text { agreement and } \\
\text { define the } \\
\text { relationship } \\
\text { between partners } \\
\text { 2. Use the } \\
\text { knowledge to } \\
\text { deal with the legal } \\
\text { affairs in the } \\
\text { partnership } \\
\text { process }\end{array}$ & $\begin{array}{l}\text { Task 2-2: } \\
\text { 1. According to the tasks assigned by the } \\
\text { teachers, the students are grouped together in } \\
\text { groups. } \\
\text { 2, The teacher will give guidance for } \\
\text { problems presented in the student discussion } \\
\text { in time at the scene. } \\
\text { 3. The teacher will make comments on the } \\
\text { partnership agreements produced by each } \\
\text { group and summarize. }\end{array}$ \\
\hline \multirow[t]{2}{*}{3} & \multirow[t]{2}{*}{$\begin{array}{l}\text { Walki } \\
\text { ng } \\
\text { into } \\
\text { comp } \\
\text { any }\end{array}$} & $\begin{array}{l}\text { 3.1 Set up a } \\
\text { company }\end{array}$ & $\begin{array}{l}\text { 11. Grasp the } \\
\text { establishment } \\
\text { conditions and } \\
\text { procedures of the } \\
\text { limited company } \\
\text { 2. Master the } \\
\text { organization of the } \\
\text { company } \\
\text { 3. Understand the } \\
\text { qualifications and } \\
\text { responsibilities of } \\
\text { company } \\
\text { directors, } \\
\text { supervisors and } \\
\text { senior executives } \\
\text { of the company }\end{array}$ & $\begin{array}{l}\text { Apply legal } \\
\text { knowledge to set } \\
\text { up a limited } \\
\text { liability company }\end{array}$ & $\begin{array}{l}\text { Task 3-2: } \\
\text { 1. The student will carry out the situation } \\
\text { simulation by group. } \\
\text { 2. A number of students are simulated to form } \\
\text { an industrial and commercial department, and } \\
\text { the remaining students are divided into } \\
\text { several groups to simulate the establishment } \\
\text { of a limited company seperately } \\
\text { 3. Each group shall assign roles to assist the } \\
\text { company to formulate the articles of } \\
\text { association and relevant documents. } \\
\text { 4. Each group shall send a representative to } \\
\text { the industrial and commercial department to } \\
\text { perform the registration procedure } \\
\text { The teacher gives a comprehensive } \\
\text { evaluation according to the establishment of } \\
\text { each group }\end{array}$ \\
\hline & & $\begin{array}{l}3.2 \\
\text { Simulate } \\
\text { meeting of } \\
\text { board of } \\
\text { directors }\end{array}$ & $\begin{array}{l}\text { Grasp the nature } \\
\text { of the company } \\
\text { organization, } \\
\text { functions and } \\
\text { powers, meeting, } \\
\text { resolution by } \\
\text { voting }\end{array}$ & $\begin{array}{l}\text { Able to use the } \\
\text { related } \\
\text { knowledge of } \\
\text { company law to } \\
\text { identify common } \\
\text { illegal behaviors }\end{array}$ & $\begin{array}{l}\text { Task 3-3: } \\
\text { 1. The students shall carry out the situation } \\
\text { simulation by group. } \\
\text { 2. Several students simulate company board } \\
\text { members, holding board meetings. } \\
\text { 3. The rest of the students watch and point out } \\
\text { the irregularities in the meeting } \\
\text { 4. Teachers give comprehensive evaluation }\end{array}$ \\
\hline \multirow{2}{*}{4} & \multirow[t]{2}{*}{$\begin{array}{l}\text { Under } \\
\text { standi } \\
\text { ng the } \\
\text { contra } \\
\text { ct }\end{array}$} & $\begin{array}{l}\text { 4.1 Sign a } \\
\text { contract, } \\
\text { pay } \\
\text { attention } \\
\text { risk control }\end{array}$ & $\begin{array}{l}\text { Master contract on } \\
\text { its application }\end{array}$ & $\begin{array}{c}\text { Able to use } \\
\text { contract related } \\
\text { law knowledge to } \\
\text { avoid risk }\end{array}$ & $\begin{array}{l}\text { Task 4-1: } \\
\text { 1. According to the typical cases provided by } \\
\text { teachers, students are grouped together in } \\
\text { groups to analyze and discuss cases. } \\
\text { 2, The teacher shall give guidance for } \\
\text { problems presented in the student discussion } \\
\text { in time at the scene. } \\
\text { 3, The teacher shall review the situation of } \\
\text { discussions of the various groups and } \\
\text { summarizes them. }\end{array}$ \\
\hline & & $\begin{array}{l}\text { 4.2 Draw } \\
\text { up a house } \\
\text { lease } \\
\text { contract }\end{array}$ & $\begin{array}{l}1 \text { Master the } \\
\text { procedure of the } \\
\text { contract } \\
\text { concluding } \\
\text { 2. Draw up a } \\
\text { housing lease } \\
\text { contract }\end{array}$ & $\begin{array}{l}\text { Able to use the } \\
\text { contract } \\
\text { concluding } \\
\text { related legal } \\
\text { knowledge to } \\
\text { draw up a house } \\
\text { lease contract } \\
\text { with complete } \\
\text { and considerate } \\
\text { content }\end{array}$ & $\begin{array}{l}\text { Task 4-2: } \\
\text { Students are required to draw up a } \\
\text { comprehensive and considerate home lease } \\
\text { contract from the landlord (landlord) and the } \\
\text { tenant safety }\end{array}$ \\
\hline
\end{tabular}




\begin{tabular}{|c|c|c|c|c|c|}
\hline & & $\begin{array}{l}4.3 \text { The } \\
\text { contract } \\
\text { effective? }\end{array}$ & $\begin{array}{l}\text { Grasp the } \\
\text { effectiveness of } \\
\text { the contract }\end{array}$ & $\begin{array}{l}\text { 1. Able to } \\
\text { independently } \\
\text { analyze the } \\
\text { effectiveness of } \\
\text { the contract and } \\
\text { effective } \\
\text { requirements } \\
\text { 2. Able to identify } \\
\text { the illegal } \\
\text { behaviors of the } \\
\text { contract } \\
\end{array}$ & $\begin{array}{l}\text { Task 4-3: } \\
\text { 1. According to the typical cases provided by } \\
\text { teachers, students are grouped together in } \\
\text { groups to analyze and discuss cases. } \\
\text { 2, The teacher shall give guidance for } \\
\text { problems presented in the student discussion } \\
\text { in time at the scene. } \\
\text { 3, The teacher shall review the situation of } \\
\text { discussions of the various groups and } \\
\text { summarizes them. }\end{array}$ \\
\hline \multirow{3}{*}{5} & \multirow[t]{3}{*}{$\begin{array}{l}\text { The } \\
\text { protec } \\
\text { tion of } \\
\text { intelle } \\
\text { ctual } \\
\text { proper } \\
\text { ty }\end{array}$} & $\begin{array}{l}5.1 \text { The } \\
\text { power of } \\
\text { the } \\
\text { trademark }\end{array}$ & $\begin{array}{l}\text { 1. Understand the } \\
\text { composition and } \\
\text { function of } \\
\text { trademarks. } 2 \text {. } \\
\text { Master the subject, } \\
\text { object and content } \\
\text { of the trademark } \\
\text { 3. Master the } \\
\text { special protection } \\
\text { of well-known } \\
\text { trademarks } \\
\end{array}$ & $\begin{array}{l}\text { Able to use } \\
\text { trademark law to } \\
\text { maintain } \\
\text { intellectual } \\
\text { property rights, } \\
\text { experience the } \\
\text { power of } \\
\text { trademark, } \\
\text { establish brand } \\
\text { awareness, }\end{array}$ & $\begin{array}{c}\text { Task 5-1: } \\
\text { Watch video: } \\
\text { Case analysis; Wang zhi and overseas rights } \\
\text { protection. Experience the power of } \\
\text { trademark, establish brand awareness, protect } \\
\text { intellectual property rights }\end{array}$ \\
\hline & & $\begin{array}{c}5.2 \\
\text { Trademark } \\
\text { infringeme } \\
\text { nt } \\
\text { judgment }\end{array}$ & $\begin{array}{l}\text { Master the } \\
\text { standard of } \\
\text { trademark } \\
\text { certification }\end{array}$ & $\begin{array}{c}\text { Use trademark } \\
\text { law knowledge to } \\
\text { judge and identify } \\
\text { trademark } \\
\text { infringement }\end{array}$ & $\begin{array}{l}\text { Task 5-2: } \\
\text { 1. According to the typical cases provided by } \\
\text { teachers, students are grouped together in } \\
\text { groups to analyze and discuss cases. } \\
\text { 2, The teacher shall give guidance for } \\
\text { problems presented in the student discussion } \\
\text { in time at the scene. } \\
\text { 3, The teacher shall review the situation of } \\
\text { discussions of the various groups and } \\
\text { summarizes them. }\end{array}$ \\
\hline & & $\begin{array}{l}5.3 \text { The } \\
\text { protection } \\
\text { of patent }\end{array}$ & $\begin{array}{l}\text { Master the criteria } \\
\text { and scope of } \\
\text { application of } \\
\text { patent } \\
\text { infringement }\end{array}$ & $\begin{array}{l}\text { Judge, identify } \\
\text { patent } \\
\text { infringement } \\
\text { behavior, master } \\
\text { the rights } \\
\text { protection skill } \\
\text { according to the } \\
\text { patent law } \\
\text { knowledge }\end{array}$ & $\begin{array}{l}\text { Task 5-2: } \\
\text { 1. According to the typical cases provided by } \\
\text { teachers, students are grouped together in } \\
\text { groups to analyze and discuss cases. } \\
\text { 2, The teacher shall give guidance for } \\
\text { problems presented in the student discussion } \\
\text { in time at the scene. } \\
\text { 3, The teacher shall review the situation of } \\
\text { discussions of the various groups and } \\
\text { summarizes them. }\end{array}$ \\
\hline \multirow[t]{2}{*}{6} & \multirow{2}{*}{$\begin{array}{l}\text { Resea } \\
\text { rch on } \\
\text { marke } \\
\quad t\end{array}$} & $\begin{array}{l}6.1 \\
\text { Maintain } \\
\text { the market } \\
\text { order and } \\
\text { fair } \\
\text { competitio } \\
\mathrm{n}\end{array}$ & $\begin{array}{l}\text { Grasp the type and } \\
\text { connotation of } \\
\text { unfair competition } \\
\text { behavior }\end{array}$ & $\begin{array}{l}\text { Able to identify } \\
\text { unfair } \\
\text { competition acts } \\
\text { in the economic } \\
\text { life }\end{array}$ & $\begin{array}{l}\text { Task 6-1: } \\
\text { 1、 Students are required to pay attention to } \\
\text { market research and give specific examples } \\
\text { of the } 11 \text { unfair competition behaviors listed } \\
\text { in unfair competition law. } \\
\text { 2、 According to the typical cases provided } \\
\text { by teachers, students are grouped together in } \\
\text { groups to analyze and discuss cases. } \\
\text { 3、 The teacher shall review the situation of } \\
\text { discussions of the various groups and } \\
\text { summarizes them. }\end{array}$ \\
\hline & & $\begin{array}{c}6.2 \\
\text { Research } \\
\text { on market }\end{array}$ & $\begin{array}{c}\text { Clear the product } \\
\text { quality obligation } \\
\text { of producers and } \\
\text { sellers }\end{array}$ & $\begin{array}{l}\text { 1. Able to use the } \\
\text { product quality } \\
\text { law knowledge to } \\
\text { supervise the } \\
\text { product quality in } \\
\text { real life } \\
\text { 2. Able to analyze } \\
\text { and deal with } \\
\text { practical }\end{array}$ & $\begin{array}{l}\text { Task 6-2: } \\
\text { Students divided into groups to use their } \\
\text { spare time to go to the surrounding } \\
\text { supermarkets and department stores to look } \\
\text { at the logo on the product or its package to } \\
\text { investigate the product packaging problems } \\
\text { and collect data, each group shall select a } \\
\text { representative to present in class, the teacher } \\
\text { shall make comments. }\end{array}$ \\
\hline
\end{tabular}




\begin{tabular}{|c|c|c|c|c|c|}
\hline & & & & $\begin{array}{l}\text { problems related } \\
\text { to product quality } \\
\text { in life }\end{array}$ & \\
\hline \multirow{3}{*}{7} & \multirow{3}{*}{$\begin{array}{l}\text { Dialo } \\
\text { gue } \\
\text { with } \\
\text { consu } \\
\text { mers }\end{array}$} & $\begin{array}{l}7.1 \\
\text { Dialogue } \\
\text { with } \\
\text { consumers }\end{array}$ & $\begin{array}{l}\text { Familiar with the } \\
\text { rights of } \\
\text { consumers } \\
\text { according to law } \\
\text { 2. Clarify the } \\
\text { obligations of the } \\
\text { operators } \\
\end{array}$ & $\begin{array}{l}\text { Able to identify } \\
\text { the operators' } \\
\text { actions against } \\
\text { consumers' rights } \\
\text { and interests }\end{array}$ & $\begin{array}{l}\text { Task 7-1: } \\
\text { Market research, dialogue with consumers. } \\
\text { Investigate and understand the behaviors that } \\
\text { infringe upon consumers' rights and interests } \\
\text { in life, collect information, each group shall } \\
\text { select a representative to make statements in } \\
\text { class, while teacher makes comments. }\end{array}$ \\
\hline & & $\begin{array}{l}7.2 \\
\text { Safeguard } \\
\text { consumers } \\
\text { rights }\end{array}$ & $\begin{array}{l}\text { Able to use } \\
\text { relevant laws to } \\
\text { properly handle } \\
\text { the issue of } \\
\text { infringing upon } \\
\text { the rights and } \\
\text { interests of } \\
\text { consumers }\end{array}$ & $\begin{array}{l}\text { 1. Able to use } \\
\text { relevant laws to } \\
\text { properly handle } \\
\text { the problem of } \\
\text { infringing upon } \\
\text { consumers' rights } \\
\text { and interests } \\
\text { 2. Guiding } \\
\text { students to feel } \\
\text { the rights and } \\
\text { interests of } \\
\text { consumers in } \\
\text { accordance with } \\
\text { the law }\end{array}$ & $\begin{array}{l}\text { Task 7-2: } \\
\text { 1. According to the typical cases provided by } \\
\text { teachers, students are grouped together in } \\
\text { groups to analyze and discuss cases. } \\
\text { 2, The teacher shall give guidance for } \\
\text { problems presented in the student discussion } \\
\text { in time at the scene. } \\
\text { 3, The teacher shall review the situation of } \\
\text { discussions of the various groups and } \\
\text { summarizes them. }\end{array}$ \\
\hline & & $\begin{array}{l}7.3 \\
\text { Consumer } \\
\text { rights } \\
\text { protection } \\
\text { way }\end{array}$ & $\begin{array}{l}\text { Grasp the } \\
\text { consumers' rights } \\
\text { protection way }\end{array}$ & $\begin{array}{l}\text { Able to use } \\
\text { relevant laws to } \\
\text { properly handle } \\
\text { disputes with } \\
\text { operators }\end{array}$ & $\begin{array}{c}\text { Task 7-3: } \\
\text { Create scene, divide the students into } \\
\text { different groups, students will act as } \\
\text { consumers and business operators, the } \\
\text { consumers association, administrative } \\
\text { departments, institutions, the court of } \\
\text { arbitration for scene simulation plays, recept } \\
\text { party's case consulting, deal with consumer } \\
\text { disputes }\end{array}$ \\
\hline \multirow[t]{3}{*}{8} & \multirow[t]{3}{*}{$\begin{array}{l}\text { Interv } \\
\text { iew } \\
\text { worke } \\
\text { rs }\end{array}$} & $\begin{array}{l}8.1 \text { Enter } \\
\text { into labor } \\
\text { relations }\end{array}$ & $\begin{array}{l}\text { Able to sign the } \\
\text { contract correctly }\end{array}$ & $\begin{array}{l}\text { Contents of labor } \\
\text { contract and } \\
\text { notices of labor } \\
\text { contract signing }\end{array}$ & $\begin{array}{l}\text { Task 8-1: } \\
\text { 1. Interview the employees to understand the } \\
\text { contents of the labor contract and the notices } \\
\text { of the contract } \\
\text { The teacher shall explain the knowledge } \\
\text { points, sign the labor contract, the teacher } \\
\text { shall make comments and revise the finalized } \\
\text { draft. }\end{array}$ \\
\hline & & $\begin{array}{l}\text { 8.2 Change } \\
\text { and the } \\
\text { termination } \\
\text { of labor } \\
\text { relations }\end{array}$ & $\begin{array}{l}\text { The contract can } \\
\text { be changed and } \\
\text { terminated } \\
\text { according to the } \\
\text { provisions of the } \\
\text { labor contract law }\end{array}$ & $\begin{array}{l}\text { Legal provisions } \\
\text { for the alteration, } \\
\text { dissolution and } \\
\text { termination of } \\
\text { labor contracts }\end{array}$ & $\begin{array}{c}\text { Task 8-2: } \\
\text { The group discusses cases and sets out } \\
\text { procedures for contract change and } \\
\text { termination. }\end{array}$ \\
\hline & & $\begin{array}{l}\text { 8.3 Deal } \\
\text { with labor } \\
\text { disputes }\end{array}$ & $\begin{array}{l}\text { Able to deal with } \\
\text { labor dispute } \\
\text { according to labor } \\
\text { law }\end{array}$ & $\begin{array}{l}\text { Procedures for } \\
\text { handling labor } \\
\text { disputes, labor } \\
\text { laws, labor } \\
\text { contract law }\end{array}$ & $\begin{array}{c}\text { Task 8-3: } \\
\text { Group discussion cases, case sharing, teacher } \\
\text { explanation, formulate labor dispute } \\
\text { settlement plan. }\end{array}$ \\
\hline 9 & $\begin{array}{l}\text { The } \\
\text { settle } \\
\text { ment } \\
\text { of the } \\
\text { econo } \\
\text { mic } \\
\text { disput }\end{array}$ & $\begin{array}{l}\text { 9.1 Write } \\
\text { pleadings }\end{array}$ & $\begin{array}{l}\text { 1. Rationalize } \\
\text { economic and } \\
\text { legal relations } \\
\text { 2. The basic } \\
\text { format of the } \\
\text { pleadings and the } \\
\text { writing of the } \\
\text { required content } \\
\text { 3. Production of } \\
\text { the evidence }\end{array}$ & $\begin{array}{l}\text { Enables students } \\
\text { to straighten out } \\
\text { economic and } \\
\text { legal } \\
\text { relationships in } \\
\text { economic and } \\
\text { legal cases, and } \\
\text { be able to make } \\
\text { pleadings and } \\
\text { evidence }\end{array}$ & $\begin{array}{l}\text { Task 9-1: } \\
\text { Watch video: } \\
\text { 1. Students should be grouped together to } \\
\text { discuss the dispute focus of the case } \\
\text { 2. According to video, prepare a civil } \\
\text { complaint for the parties, and make a copy of } \\
\text { the evidence catalogue according to the } \\
\text { evidence provided by the parties and the } \\
\text { evidence collected. } \\
\text { 3. Teachers should give timely guidance to }\end{array}$ \\
\hline
\end{tabular}




\begin{tabular}{|c|c|c|c|c|}
\hline e & & catalogue & catalogues. & $\begin{array}{l}\text { the problems presented in the discussion of } \\
\text { students. } \\
\text { 4. The teacher shall make comments on the } \\
\text { problems in the complaint and evidence } \\
\text { categories produced by the groups and } \\
\text { summarize the problems. }\end{array}$ \\
\hline & $\begin{array}{l}9.2 \text { Moot } \\
\text { court }\end{array}$ & $\begin{array}{l}\text { 1. Master the } \\
\text { relevant legal } \\
\text { system of civil } \\
\text { litigation } \\
\text { 2. Master civil trial } \\
\text { procedures }\end{array}$ & $\begin{array}{l}\text { 1. Study relevant } \\
\text { laws and } \\
\text { regulations to } \\
\text { improve legal } \\
\text { literacy } \\
\text { 2. Improve } \\
\text { teamwork spirit } \\
\text { and complete } \\
\text { tasks together } \\
\text { 3. The cultivation } \\
\text { and promotion of } \\
\text { the ability of } \\
\text { knowledge } \\
\text { understanding } \\
\text { and usage }\end{array}$ & $\begin{array}{c}\text { Task 9-2: } \\
\text { Moot court } \\
\text { 1. Set situation data, carry out scenario } \\
\text { simulation play by divided into litigants, } \\
\text { lawyers and court group, lawyer group shall } \\
\text { receive consulting cases, act as the agent ad } \\
\text { litem, court group form a collegial panel in } \\
\text { accordance with the law. } \\
\text { 2. Simulate opening a court session }\end{array}$ \\
\hline
\end{tabular}

\section{Third, the innovation of teaching mode}

The innovation of the teaching mode of this course lies at

(1)The innovation of teaching content. The innovation of the teaching mode of this course lies at that it puts the teaching content in the practical situation, and carries out the experiential learning so as to realize the integration of teaching, learning and practice, accomplished the training objectives of three aspects: knowledge, ability and quality around the economic law teaching content.(2) The innovation of teaching method. This course will carry out teaching activities with real tasks with students required to work together to complete the task by divided into groups. It cultivates both the practical ability and their cooperation spirit and cooperation ability. (3)Innovation in the way of assessment. The assessment of this course is divided into two main parts: ordinary performance and learning effect. However, students' attendance, learning activities, team activities and assignments will make up a significant proportion of the overall results.

In conclusion, higher vocational economic law project teaching design should achieve two goals, they are: vocational education objective and economic law course teaching objective.

\section{References}

[1] Economic Law, Shanghai University of Finance And Economics, Lu Zhen Jie, editor-in-chief.

[2] Economic law, Metallurgical Industry Press, Sun Jin Gang, editor-in-chief. 